\title{
The Moderating Effect of Equity Incentive on Slack and R \& D Investment
}

\author{
Mingzhu Liü, a, ShuJun Ye $2, b$ \\ ${ }^{1}$ School of Economics and Management, Beijing Jiaotong University, Beijing 100044, China \\ ${ }^{2}$ School of Economics and Management, Beijing Jiaotong University, Beijing 100044, China \\ aliumingzhu4939@foxmail.com, bshjye@bjtu.edu.cn
}

Keywords: Equity incentive, Slack, R\&D investment.

\begin{abstract}
The R\&D activities of an enterprise play an important role in improving its core competitiveness, and the research and development is based on a large amount of resources. The slack of the enterprise can provide support for $R \& D$ investment, executive equity incentive can regulate the relationship between them. In this paper, we choose the non-financial companies in China's A-share market in 2009-2015 as the research sample, and establish the multiple regression equation, then test the influence of the company's slack and executive equity incentives on R\&D investment. We argue that slack has a significant role in promoting $R \& D$ investment. Further studies showed that as a kind of corporate governance mechanism, the equity incentive can alleviate the management agency problem in the use of slack holding, mitigate financial constraint in innovation, increase the enterprise $\mathrm{R} \& \mathrm{D}$ investment.
\end{abstract}

\section{Introduction}

As an important way to enhance the innovation ability and core competitiveness of enterprises, R \& D investment is of great significance to the growth and development of enterprises. The characteristics of R \& D investment are reflected in the long cycle, large investment, uncertain income and so on [1]. In addition, due to the existence of information asymmetry in the investment process, there is a serious relationship between senior management and investors. The externality of R\&D investment also restricts the investment decision of investors [2]. Therefore, it is difficult to solve the problem of financing through external financing. The financing of internal financing comes from the inside of the enterprise has a natural advantage in terms of access capital. Internal financing can be an important source of funding for R \& D innovation when external investment is severely constrained.

Slack, also known as organizational redundancy, refers to such excess resources as underutilized overhead and financial reserves in enterprises. Redundant resources are financial or other resources that are accumulated in business operations, can be used to influence the strategic decisions of firms, such as mergers and acquisitions. This redundant resource provides innovative resources for businesses when face financing constraints [3]. In fact, as a phenomenon prevalent in production and management, companies do not have specific arrangements for slack. Many scholars' studies have also shown that slack provide discretionary discretion for senior managers in resource domination, offering some protection against uncontrollable change and downside risk.

Chrisman (2012) argues that slack can provide some support for strategic development, such as the development of new products or new market development when companies are more difficult to obtain resource support from the external environment [4]. In addition, it has been found that equity incentive for executives can effectively play the supervisory role of internal governance mechanism, thus inhibiting the abuse of corporate redundant resources by management.

Based on the above analysis, this paper discusses and examines the impact of slack on $\mathrm{R} \& \mathrm{D}$ investment, and as a means to solve the principal-agent problem, whether the equity incentive can effectively alleviate the problem of holding and utilizing the slack, so as to improve the effective use of organizational redundancy in enterprise innovation. 


\section{Theory and Hypotheses}

2.1 Slack and $\mathbf{R} \& \mathbf{D}$ investment. The impact of slack on $\mathrm{R} \& \mathrm{D}$ investment is reflected in two ways. On the one hand, slack as a living resource that exists within the enterprise provide important resource for enterprise $R \& D$. On the other hand, slack is conducive to $R \& D$ investment in this high-risk and income uncertain activities [5]. Because of the buffer characteristics of slack, managers are more willing to carry out new products and new technologies and new market development and innovation. In addition, taking into account the manager's reputation, a large number of accumulated slack within the enterprise will face the risk of exposure, so that shareholders believe that managers have the problem of "waste" and "poor executive ability" [6]. In order to protect their reputation from excessive redundancy, managers at all levels are motivated by the efficient use of these slack. Therefore, managers have the motivation to integrate the slack and play the due value of slack, such as put it into new products, new technologies, new markets.

2.2 Equity Incentive as Moderators of the Slack Effect. The study of executive equity incentive and slack and R \& D investment is considered to solve the problem of agency between managers and shareholders, which can help to promote the effective use of slack [7]. The incentive mechanism plays a positive role in guiding technological innovation, tilting the company's redundant resource allocation to innovation project. In dealing with slack, executives are more motivated to invest in research and development. This not only achieves the efficient use of redundancy, but also promotes R \& D investment to improve the company's ability to innovate. And ultimately achieve their own and business win-win [8].

In summary, the hypothesis:

H1: equity incentive has a positive moderating effect on the impact of slack on R \& D investment.

\section{Methodology}

3.1 Data and Variables. In this paper, the A-share companies listed on the Shanghai Stock Exchange and the Shenzhen Stock Exchange from 2009 to 2015 were selected as data samples. In order to avoid data deviation, the following companies were excluded:(1) financial listed companies; (2) ST, PT, * ST listed companies during the sample period; (3) companies that do not disclose R \& D data.

The choice of independent variable is $\mathrm{R} \& \mathrm{D}$ investment $(R \& D)$. In this paper, we follow the measurement method proposed by scholars before, using $R \& D$ investments in millions of RMB divided by the firm's annual sales as independent variable.

Slack is measured following Wei Min and Wei Huaqian (2016). Using unabsorbed slack (UnAbSlack) and absorbed slack (AbSlack) measure the slack of enterprises. The difference between the quick ratio and the industry median were chosen to measure the unabsorbed slack at the industry level. As a measure of absorbed slack at the industry level, we use the ratio of sales revenue and management expenses to operating income to subtract the industry median. This article draws on indicators of domestic and foreign researchers, selected the ratio of shares of equity incentive and total share capital to measure equity incentive (Incentive).

3.2 Model Building. In order to test the moderating effect of equity incentive on the relationship between slack and R \& D investment:

$$
\begin{aligned}
& R \& D_{i, t}=\alpha+\beta_{1} \text { UnAbslack }_{i, t}+\beta_{2} \text { Abslack }_{i, t}+\beta_{3} \text { Incentive }_{i, t} * \text { UnabSlack }_{i, t}+\beta_{4} \text { Incentive }_{i, t} * \text { Abslack }_{i, t} \\
& +\beta_{5} \text { Incentive }_{i, t}+\beta_{6} \text { Size }_{i, t}+\beta_{7} \text { Growth }_{i, t}+\beta_{8} \text { Roa }_{i, t}+\beta_{9} \text { Lev }_{i, t}+\beta_{10} C f o_{i, t} \varepsilon_{\mathrm{i}, \mathrm{t}}
\end{aligned}
$$

\section{Results}

4.1 Data Description. Descriptive statistics of the variables are shown in table 1. Table 1 statistical results show that the average ratio of $\mathrm{R} \& \mathrm{D}$ expenditures and operating income of $\mathrm{A}$ shares in China is $19 \%$. From the comparison of absorbed slack and unabsorbed slack, each value of 
unabsorbed slack value is higher, which shows that the categories of redundant resources are very different in our country. The maximum value of unabsorbed slack is 31.03 , indicating that some of the internal redundant resources accumulated. Table 1 also reports the results of descriptive statistical analysis of firm performance (Roa), Cfo, asset liability level (Lev), firm size (Size), firm growth (Grow), and operating cash flow.

Table 1. Data description.

\begin{tabular}{cccccc}
\hline Variable & mean & Median & standard deviation & minimum & maximum \\
\hline Incentive & 0.019737 & 0.0177 & 0.014949 & 0.0005 & 0.0892 \\
\hline UnAbSlack & 2.889247 & 1.63291 & 4.126599 & 17.02882 & 0.359718 \\
\hline AbSlack & 0.269994 & 0.223853 & 0.157489 & 0.038037 & 0.695159 \\
\hline Size & 21.76889 & 21.57189 & 1.067802 & 20.00134 & 25.21266 \\
\hline Growth & 0.481957 & 0.298214 & 0.668984 & -0.45461 & 4.361921 \\
\hline Roa & 7.101345 & 6.296201 & 5.701312 & -8.08714 & 35.13843 \\
\hline R\&D & 0.022231 & 0.009041 & 0.038352 & $9.12 \mathrm{E}-06$ & 0.338436 \\
\hline Lev & 4.856232 & 3.192935 & 5.758429 & 1.227105 & 41.00691 \\
\hline Cfo & $1.97 \mathrm{E}+08$ & 91307602 & $9.41 \mathrm{E}+08$ & $-5 \mathrm{E}+09$ & $6.77 \mathrm{E}+09$ \\
\hline
\end{tabular}

4.2 Empirical Analysis. The data used in this paper is unbalanced panel data, and is the typical large $\mathrm{N}$ small $\mathrm{T}$ data. According to the test standard of econometrics, it is not necessary to carry out the stationarity test and cointegration test.

Table 2 reports the regression effect of equity incentive on slack and R \& D investment. From table 2, the coefficient of the interaction term of executive equity incentive and organizational slack is positive and at the $1 \%$ level and $\mathrm{R} \& \mathrm{D}$ investment intensity is significantly, showing the executives equity incentive plays a positive role between slack and corporate R \& D investment, verify the hypothesis 1 . It means that executive equity incentive can effectively alleviate the problem of information asymmetry and principal-agent problem, prompting enterprises to attach importance to slack, effectively play the role of slack in supporting enterprise innovation, reducing internal conflicts and mitigating environmental uncertainties, so as to help executives make full use of redundant resources for enterprises to establish a competitive advantage.

Table 2. Empirical results.

\begin{tabular}{ccc}
\hline Variable & Coefficient & t-Statistic \\
\hline Incentive & $0.483^{* * *}$ & 3.69 \\
\hline UnAbSlack & $0.00979^{* *}$ & 2.01 \\
\hline AbSlack & $0.123^{* * *}$ & 3.02 \\
\hline Incentive* UnAbSlack & $0.0761^{* *}$ & 2.63 \\
\hline Incentive* UnAbSlack & $2.242^{* *}$ & 2.21 \\
\hline Size & 0.00276 & 0.80 \\
\hline Growth & $0.0103^{* * *}$ & 3.20 \\
\hline Roa & -0.00000528 & -0.01 \\
\hline Lev & $-0.00232^{* *}$ & 2.22 \\
\hline Cfo & $-4.04 \mathrm{e}-12$ & -1.37
\end{tabular}

Key: $* * *$ denotes $\mathrm{p}$ value of less than $0.001 ; * *$ denotes $\mathrm{p}$ value of less than $0.01 ; *$ denotes $\mathrm{p}$ value of less than 0.05

\section{Conclusion}

This paper analyzes the influence of slack on $\mathrm{R} \& \mathrm{D}$ investment and the moderating effect of executive equity incentive on slack and $R \& D$ investment. The results show that: (1) There is a positive relationship between slack and R \& D investment. Slack has a role in promoting R \& D investment. As an important way to enhance competitive advantage, innovation is of great importance for enterprises. Slack provide resources for organizational change and innovation, improve the risk taking of executives. (2) With the increase of equity incentive, the promotion effect of slack on $\mathrm{R} \& \mathrm{D}$ investment will be enhanced, that is, equity incentive has a positive moderating 
effect on redundant resources and R \& D investment. Equity incentive can play the internal governance mechanism of supervision and incentive effect, effectively alleviate the agency problems, motivate managers, which is propitious to optimize the allocation of internal resources redundancy, improve business performance.

\section{References}

[1] Li, J., \& Tang, Y. CEO hubris and firm risk taking in China: The moderating role of managerial discretion. Academy of Management Journal, vol.53, pp. 45-68, 2010.

[2] Wang Yan, He Xinwen, Liang Laixin. Property right type, organizational slack and selfrenovation investment: Evidence from Chinese listed. companies. Science of Science and Management of S.\& T. vol.32, pp. 140-147, 2011.

[3] Fang Runsheng, Wang Changlin. Review on the theory of organizational redundancy [J]. Journal of Zhongyuan University of Technology, vol.19, pp. 13-18, 2008.

[4] Chrisman, J. J., \& Patel, P. C. Variations in R\&D investments of family and nonfamily firms: Behavioral agency and myopic loss aversion perspectives. Academy of Management Journal, vol.55, pp. 976-997, 2012.

[5] Lv Changjiang, Zhang Haiping. Effect of equity incentive plan on corporate investment behavior [J]. Management World, vol.11, pp. 118-126, 2011.

[6] Li Xiaoxiang, Huo Guoqing. Study on the mechanism of organizational redundancy to product innovation [J]. Research Management, vol.36, pp. 72-79, 2015.

[7] Xu Ning. The promotion effect of executive stock option incentive on R\&D investment in high tech companies: an empirical study from a nonlinear perspective [J]. Science and Technology Management, vol.34, pp. 12-19, 2013.

[8] Xie Weimin, Wei Huaqian. Market competition, organizational slack and corporate R \& D investment [J]. China soft science, vol.8, pp. 102-111, 2016. 